\title{
PENINGKATAN LITERASI KEUANGAN PADA MASYARAKAT DESA CIGUDEG DALAM PEMBUATAN LAPORAN KEUANGAN SEDERHANA (Komunitas Pengusaha Berjenjang Produk Oriflame)
}

\author{
R Ai Lutfi Hidayat', Juitania,2,, Fitri Sagantha,,,,Andri S,4,,Adi Sofyana Latif,, \\ S1 Akuntansi, Fakultas Ekonomi, Universitas Pamulang \\ 1'dosen02243@unpam.ac.id; ${ }^{2}$ dosen02219@unpam.ac.id; ${ }^{3}$ dosen02329@unpam.ac.id; ${ }^{4}$ \\ dosen00987@unpam.ac.id; ${ }^{5}$ dosen01608@unpam.ac.id
}

\begin{abstract}
Abstrak
Permasalahan yang dimiliki oleh pengusaha yang tergabung dalam komunitas berjenjang produk Oriflamme di desa Cigudeg adalah kurangnya pemahaman mengenai pencatatan laporan keuangan khususnya laporan keuangan secara sederhana.Tim pengabdi memutuskan untuk memberi pelatihan secara kontinue selama 1 bulan yang di bagi menjadi 3 periode yaitu tanggal 13,20 dan 27 Oktober 2019. Kontinuitas ini perlu dilakukan untuk memberikan efek yang lebih mendalam bagi peserta pelatihan sehingga peserta pelatihan dapat memaksimalkan materi pelatihan untuk bisa diaplikasikan dalam bisnis yang sedang dijalankan, sehingga semua pemasukan dan pengeluaran bisa tercatat dengan rapi, yang pada akhirnya bisa mengetahui berapa keuntungan yang diperoleh setiap bulannya. Pemberian materi akan dilakukan oleh para dosen Universitas Pamulang yang sudah berpengalaman mengajar Akuntansi. Selain itu, penentuan narasumber juga didasarkan dari latar belakang setiap pengajar agar pengajar dapat memberikan materi ajar dengan cara yang mudah dipahami oleh para peserta pelatihan sehingga para peserta pelatihan dapat menangkap konsep-konsep dalam pencatatan laporan keuangan secara sederhana dan menerapkan pencatatan tersebut dalam menjalankan usahanya dengan pencatatan setiap hari.
\end{abstract}

Kata kunci: Laporan keuangan sederhana; Literasi keuangan.

\section{Abstract}

The problem that is owned by entrepreneurs who are members of the tiered community of oriflamme products in the village of Cigudeg is a lack of understanding regarding the recording of financial statements, especially simple financial reports. The service team decided to provide continuous training for 1 month which was divided into 3 periods, namely 13,20 and 27 October 2019. This continuity needs to be done to have a more profound effect on the training participants so that the training participants can maximize the training material to be used in the business that is being run, so that all income and expenses can be recorded neatly, which in the end can find out how much profit is obtained each month. The lecturers of Pamulang University who have experience teaching accounting will provide the material. In addition, the selection of resource persons is also based on the background of each teacher so that the instructor can provide teaching material in a way that is easy for the training participants to understand so that the training participants can grasp the concepts in recording financial statements simply and apply this recording in running their business by recording every day.

Keywords : Simple financial repor; Financial literacy. 


\section{PENDAHULUAN}

Cigudeg merupakan kecamatan yang terdiri dari 15 desa. Desa Cigudeg memiliki total penduduk sebanyak 13.336, yang terdiri 6.918 laki-laki dan 6.418 perempuan. Desa Cigudeg memiliki luas daerah seluas 9.48 $\mathrm{Km} 2$ dengan kepadatan penduduk sebanyak 1.406,75 jiwa $/ \mathrm{km} 2$. Dengan luas daerah 9.48km2, desa Cigudeg memiliki jumlah keluarga sebanyak 3.537 yang terbagi kedalam 65 Rukun Tetangga dan 22 Rukun Warga. Data tersebut berdasarkan data Badan Pusat Statistik Kabupaten Bogor pada tahun 2018.

Mata pencaharian penduduk di desa Cigudeg sebagian besar masih bergerak di sektor pertanian dan perkebunan. Tanaman yang ditanam oleh masyarakat desa Cigudeg yaitu tanaman padi dan palawija. Seiring dengan perkembangan Desa Cigudeg, Masyarakat Desa Cigudeg menempuh pendidikan sampai jenjang Sekolah Menengah Atas sehingga mayoritas penduduk tsb bekerja sebagai buruh pertambang.

Desa Cigudeg termasuk kedalam kategori desa berkembang, karena Desa Cigudeg telah didukung fasilitas yang dapat menunjang kegiatan sehari-hari masyarakat, fasilitas umum yang terdapat di Desa Cigudeg di antaranya akses transportasi yang mudah dan jalan raya yang sudah baik, dengan adanya kemudahan akses transportasi sehingga berpengaruh meningkatkan perekonomian dan daya beli terhadap produk-produk bahan pokok maupun sekunder seperti produk kecantikan dan kesehatan oleh masyarakat Desa Cigudeg.

Oriflame salah satu perusahaan yang konsen terhadap produk kecantikan dengan menggunakan bahan alami. Oriflame didirikan pada tahun 1967, saat ini Oriflame telah menjadi perusahaan kecantikan internasional dengan sistem penjualan langsung di lebih dari 60 negara di seluruh dunia. Portfolio yang luas dari produkproduk kecantikan Swedia yang alami, inovatif dipasarkan melalui melalui tenaga penjualan sekitar 3.600 .000 konsultan mandiri, yang bersama-sama membuat penjualan tahunan melebihi 1,5 miliar. Oriflame ingin menciptakan suatu perusahaan kosmetika yang menawarkan jenis kosmetika yang berbeda dari yang lain, yaitu yang mengandung bahan dasar alami. Mereka juga ingin memperkenalkan metode distribusi produk yang baru yang inovatif yaitu menjual produk yang dihasilkannya langsung ke rumah rumah setiap orang. Sedangkan di Indonesia sendiri, Oriflame didirikan sejak tahun 1986 dan telah berjaya di Indonesia selama 33 tahun. Oriflame 
memiliki 12 cabang dan ribuan konsultan yang tersebar luas di seluruh Indonesia. Oriflame menjual sekitar 800 jenis produk kosmetik dan perawatan kulit, yang terbuat dari bahan-bahan alami serta aman untuk kesehatan kulit.

Membangun suatu usaha, ada banyak hal yang perlu dilakukan. Mulai dari memikirkan ketersediaan stok barang, kinerja pegawai, sampai cara memasarkan produk. Namun, ada satu hal yang seringkali terlupa dalam menentukan kelanjutan usaha dan taktik ke depannya. Di mana hal tersebut adalah laporan keuangan. Banyak pelaku usaha, terutama yang masih pemula, berpikir bahwa membuat laporan keuangan yang tersusun rapih dan jelas bukanlah hal utama dalam berbisnis. Bagaimanapun juga, yang paling penting dari mengelola bisnis ya tentu kegiatan berbisnis itu sendiri. Memang, menjalankan bisnis yang ada saat ini sangatlah penting, namun sebagai pelaku usaha juga harus memastikan kalau bisnis atau usaha yang sedang dijalankan bisa terus menghasilkan keuntungan dan maju. Bagaimana cara pelaku usaha dapat mengetahui jika bisnis atau usahanya maju dan menghasilkan keuntungan, hal tersebut dapat dilihat dari laporan keuangan.

Sebuah laporan keuangan dapat mencatat seluruh perubahan aliran keuangan usaha atau bisnis yang dilakukan. Mulai dari aset seperti bangunan, jumlah stok barang, pengeluaran, pemasukan, hingga tanggaltanggal terjadinya perubahan status keuangan. Dalam laporan keuangan yang baik, seluruh perubahan keuangan sekecil apapun, harus dicatat. Sebab, catatan yang ekstra lengkap tersebutlah yang akan memberikan gambaran nyata akan keadaan usaha saat ini. Laporan keuangan dapat menggambarkan apakah usaha atau bisnis yang sedang dilakukan benar-benar berkembang atau tidak. Sebagai pelaku usaha dapat memeriksa laporan keuangan. Bisa saja ternyata usaha yang kita jalankan tidak mendapatkan banyak keuntungan karena pelaku usaha menggunakan keuntungan usahanya untuk membeli kebutuhan pribadi atau mungkin saja keuntungan yang didapat tidak sebanyak biasanya karena ada pelanggan yang belum membayar. hal-hal seperti itulah yang bisa diperjelas dengan laporan keuangan. Pelaku usaha tidak perlu merasa kebingungan kemana keuntungan tersebut hilang. Selain itu juga Laporan keuangan dapat dengan mudah menunjukkan produk mana yang paling digemari oleh konsumen, mana yang biaya modalnya paling mahal, dan produk mana yang paling menguntungkan. Dengan mengetahui hal-hal tersebut, pelaku usaha dapat melakukan 
perubahan yang sesuai. Seperti meningkatkan stok barang, menambahkan promo-promo potongan harga terhadap produk yang kurang laku di pasaran. Sebagai pelaku usaha harus dapat membuat laporan keuangan sendiri. Ketika usaha yang dilakukan sudah cukup berkembang dan sebagai pelaku usaha mulai kehabisan waktu untuk membuat laporan keuangan sendiri, barulah pelaku usaha boleh mempekerjakan akuntan untuk membantu. Membuat laporan keuangan sendiri sebenarnya bukanlah hal yang sulit untuk dilakukan. Pelaku usaha hanya perlu mencatat setiap kali ada perubahan status keuangan dalam usaha, seberapa banyak, keterangan tambahan, dan simpan buktinya transaksi-transaksi tersebut.

Endah puspa ningsih merupakan salah satu konsultan Oriflame yang berada di Indonesia dengan pencapaian jabatan dalam jaringannya saat ini adalah Direktur. Jaringan yang ada di bawah Endah Puspa ini mencapai 170 orang dengan berbagai latar belakang yang berbeda. Oleh karena itu, untuk meningkatkan kapabilitas yang ada dalam diri setiap jaringannya, maka Endah menganggap perlu untuk mengadakan pelatihan mengenai pengaturan keuangan secara sederhana.

Literasi keuangan merupakan kebutuhan dasar bagi setiap orang agar terhindar dari masalah keuangan. Kesulitan keuangan bukan hanya fungsi dari pendapatan semata (rendahnya pendapatan), kesulitan keuangan juga dapat muncul jika terjadi kesalahan dalam pengelolaan keuangan (missmanagement) seperti kesalahan penggunaan kredit, dan tidak adanya perencanaan keuangan. Keterbatasan keuangan dapat menyebabkan stress, memiliki rasa tidak percaya diri, bahkan untuk sebagian keluarga kondisi tersebut dapat berujung pada konflik keluarga. Memiliki literasi keuangan, merupakan hal yang penting untuk mendapatkan kehidupan yang sejahtera, dan memiliki kualitas hidup yang tinggi. Memiliki pemahaman tentang literasi keuangan atau pengetahuan tentang keuangan yang baik merupakan hal yang wajib dimiliki oleh pelaku usaha.

Terdapat kesalahan-kesalahan dalam pengelolaan keuangan yang dilakukan oleh komunitas oriflame. tidak menggaji diri sendiri, tidak mempertimbangkan adanya kemungkinan terburuk, mencampur aset bisnis dan pribadi, menggunakan kas usaha untuk keperluan pribadi dan tidak memiliki laporan keuangan sederhana. Kesalahankesalahan tersebut bukan merupakan hal-hal yang sengaja dilakukan oleh para pelaku tetapi hal tersebut disebabkan oleh kurangnya pengetahuan tentang perencanaan dan 
pengelolaan keuangan. Literasi keuangan membantu memahami pengelolaan keuangan dan peluang untuk mencapai kehidupan yang lebih sejahtera di masa yang akan datang.

Dari latar belakang tersebut, sebagai bentuk pengabdian kami kepada masyarakat, Universitas Pamulang bekerja sama dengan Komunitas Oriflame Bogor untuk menyelenggarakan pelatihan akuntansi Komunitas Oriflame dengan tema Peningkatan Literasi Keuangan pada Masyarakat Desa Cigudeg dalam Pembuatan Laporan Keuangan Sederhana. (Komunitas Pengusaha Berjenjang Produk Oriflame).

\section{METODE}

Metode yang digunakan dalam Pengabdian Kepada Masyarakat ini adalah dengan memberikan pelatihan secara berkala kepada para pengusaha yang tergabung dalam komunitas oriflame di desa Cigudeg kabupaten Bogor. Pelatihan akan dilakukan secara berkala selama 1 bulan. Dalam pertemuan pertama akan diberikan materi pelatihan bagaimana cara membuat laporan keuangan secara sederhana yang diisi oleh Raden Ai Lutfi Hidayat, S.E., M.E. Yang bersangkutan adalah Magister Ekonomi dari Universitas Trisakti. Raden Ai Lutfi Hidayat, S.E., M.E. memberikan pelatihan literasi keuangan dengan materi pencatatan laporan keuangan sederhana mulai dari pencatatan uang keluar, uang masuk sampai pembuatan laporan laba rugi secara sederhana. Walaupun materi ajar dianggap merupakan materi yang sangat dasar, tetapi Raden Ai Lutfi Hidayat, S.E., M.E. menyajikan materi secara interaktif sehingga setiap peserta pelatihan lebih mudah memahami dan langsung mempraktikkan materi ajar yang disajikan. Selain itu, Raden Ai Lutfi Hidayat, S.E., M.E. memberikan materi dengan disisipkan permainan tentang materi ajar yang di dalamnya terdapat doorprize, sehingga peserta menjadi lebih tertarik dengan materi yang disiapkan. Fitri Sagantha, S.E.Sy., M.E., sebagai pemandu acara memandu acara dengan meriah, sehingga pada pertemuan pertama para peserta menjadi lebih tertarik terhadap pencatatan keuangan sederhana di dalam bisnis yang sedang dijalankan. Pada akhir sesi Juitania, S.Pd., M.Pd. memberian kuesioner untuk melihat respons para peserta dalam menanggapi materi yang telah disampaikan, sehingga pertemuan kedua nanti bisa lebih efektif dalam pemberian materi sesuai dengan sasaran yang diharapkan oleh para peserta.

Pertemuan kedua dilakukan pada selang satu minggu setelah pertemuan 
pertama yaitu tanggal 20 Oktober 2019. Pertemuan kedua disajikan oleh Andri Sjahputra, S.E., M.M. yang merupakan lulusan dari Universitas Trisakti. Pertemuan kedua ini Andri Sjahputra, S.E., M.M menyajikan materi tentang pembuatan Cash Flow secara sederhana. Pelatihan tentang bahasan ini menjadi penting karena pencatatan tersebut harus dilakukan setiap hari ketika akan mengeluarkan uang ataupun mendapatkan uang dari hasil penjualan produk Oriflame. Untuk mempermudah pembuatan Cash Flow maka Andri Sjahputra, S.E., M.M menyajikan format pemasukan dan pengeluaran beserta rekapitulasi dari setiap transaksi yang biasa terjadi pada bisnis oriflame yang sedang dijalankan oleh para peserta.

Setelah penjelasan format Cash Flow, Andri Sjahputra, S.E., M.M membagikan langsung format yang telah diprint out kepada seluruh peserta untuk mempraktikkan pencatatan cash flow sederhana yang telah di sampaikan dalam materi. Pada praktik pembuatan cash flow selain pemateri yang memimpin langsung, para peserta didampingi oleh fasilitator Fitri Sagantha, S.E.Sy., M.E., dan Juitania, S.Pd., M.Pd. sehingga para peserta dapat dengan mudah mengerti bagaimana cara pencatatan cash flow sederhana yang menjadi output penting dalam pelatihan pertemuan kedua. Pada akhir sesi Adi Sofyana Latif, S.Si., M.M., dan Raden Ai Lutfi Hidayat, S.E., M.E. membuat permainan dengan bahan materi yang telah disampaikan yang berhadiah paket sembako untuk para peserta pelatihan. Hal ini perlu dilakukan mengingat sebagian besar peserta pelatihan mayoritas merupakan ibu-ibu rumah tangga. Motivasi pemberian hadiah merupakan cara yang efektif untuk memaksimalkan daya fokus peserta pelatihan.

Seminggu selanjutnya tanggal 27 Oktober 2019 merupakan giliran Adi Sofyana Latif, S.Si., M.M., dengan materi praktek pembuatan pencatatan Laporan Laba Rugi. Untuk mempermudah praktek, pemateri membuat format laporan laba rugi yang telah diprint out, sehingga pada saat berjalannya praktek para peserta bisa langsung mencatat dari semua pendapatan dan biaya-biaya yang terjadi pada bisnis oriflame yang dijalankan. Dalam mempraktekan materi tersebut, para peserta didampingi oleh fasilitator Fitri Sagantha, S.E.Sy., M.E., dan Juitania, S.Pd., M.Pd., sehingga jika ada pertanyaan bisa langsung dijelaskan. Praktek membuat laporan laba rugi berjalan dengan efektif, terlihat dari form yang diisi dengan tepat mana yang tergolong pendapatan dan mana yang 
tergolong biaya. Pada pelatihan terakhir ini ditutup dengan pembagian sembako kepada para peserta berikut kuesioner, sebagai tolak ukur penilaian atas PKM yang telah dijalankan.

Setelah ketiga narasumber memberikan materi mengenai literasi keuangan yang terdiri dari materi pencatatan laporan keuangan sederhana, dilanjutkan dengan peraktek dalam pembuatan cash flow secara sederhana dan terakhir dengan pembuatan laporan Laba-Rugi. Kuesioner yang telah dibagikan sebagai tolak ukur untuk mengetahui perkembangan kemampuan dan minat peserta pelatihan terhadap literasi keuangan dengan materi yang telah disampaikan. Hasil dari pelatihan ini akan dilaporkan dalam bentuk manuskrip yang dikirim kepada jurnal pengabdian kepada masyarakat.

\section{HASIL DAN PEMBAHASAN}

Metode yang digunakan dalam pelatihan literasi keuangan dengan materi pencatatan laporan keuangan sederhana, dilanjutkan dengan peraktek pembuatan cash flow secara sederhana dan terakhir yaitu peraktek pembuatan laporan Laba-Rugi adalah dengan memberikan pelatihan secara berkala selama 1 bulan dengan dilatih oleh dosen-dosen dari Universitas Pamulang. Pelatihan dimulai dari tanggal 13 Oktober sampai dengan tanggal 27 Oktober 2019. Lokasi pengabdian masyarakat berada di Kampung Cijeuray RT 04 Desa Cigudeg Kabupaten Bogor (masyarakat dan komunitas pengusaha berjenjang produk Oriflame).

Pelatihan menekankan pada kemampuan literasi keuangan dan laporan sederhana karena berdasarkan hasil pre test yang tim pengabdian berikan memiliki hasil yang rendah terkait pengetahuan mengenai laporan keuangan. Diperlukan pelatihan khusus agar terdapat perubahan pada hasil post-test.

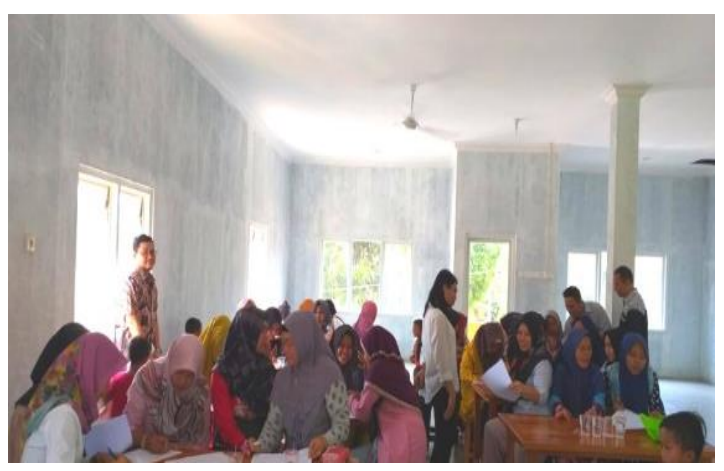

Gambar 1. Peserta PKM Melakukan Praktik Pencatatan Keuangan

Selain itu, wawacara dilakukan untuk menggali informasi lebih mendalam perihal pengetahuan literasi dan laporan keuangan. wawancara juga diberikan untuk mengetahui sejauhmana peserta pelatihan mengetahui tentang literasi dan laporan keuangan. Berdasarkan hasil perhitungan terhadap posttest, tim pengabdi mendapatkan hasil bahwa 
tidak terdapat perubahan signifikan antara hasil mean pre-test dan post-test hasil literasi keuangan. Sedangkan untuk pemahaman perihal laporan keuangan mengalami perubahan signifikan. Sebelum diberikan pelatihan, (masyarakat dan komunitas pengusaha berjenjang produk Oriflame) tidak mengetahui banyak perihal literasi keuangan dan laporan keuangan. namun, hasil yang berbeda terjadi setelah diberikan tindakan pelatihan selama 1 bulan.

Dengan kata lain, pelatihan literasi keuangan dalam pembuatan laporan keuangan sederhana perlu diadakan lebih lama lagi agar memiliki dampak lebih mendalam bagi masyarakat dan komunitas pengusaha berjenjang produk Oriflame. Hal ini terjadi karena kemampuan awal yang dimiliki masyarakat dan komunitas pengusaha berjenjang produk Oriflame masih jauh dari sempurna dalam pembuatan laporan keuangan. Selain itu, dosen tim pengabdi hanya mampu mengajar selama 2 jam dalam 1 minggu. Hal ini terjadi karena baik masyarakat dan komunitas pengusaha berjenjang produk Oriflame maupun dosen Universitas Pamulang memiliki jadwal yang padat.

Walaupun dalam kemampuan literasi keuangan dan laporan keuangan sederhana masih rendah, masyarakat dan komunitas pengusaha berjenjang produk Oriflame berprestasi di bidang lain, yaitu dalam penjualan produk Oriflame.

Hal ini merupakan tantangan yang dipikirkan oleh tim pengabdi. Namun, ada sisi positif yang didapatkan dari pelatihan yang sudah diadakan selama 1 bulan, yaitu masyarakat dan komunitas pengusaha berjenjang produk Oriflame yang sangat cepat menerima pelajaran. Dengan demikian, dengan memberikan pelatihan kembali pada semester selanjutnya akan diharapkan sudah memberikan hasil positif pada nilai rata-rata perubahan post-test dari nilai pre-test nya.

Gambar 2. Narasumber dan Peserta

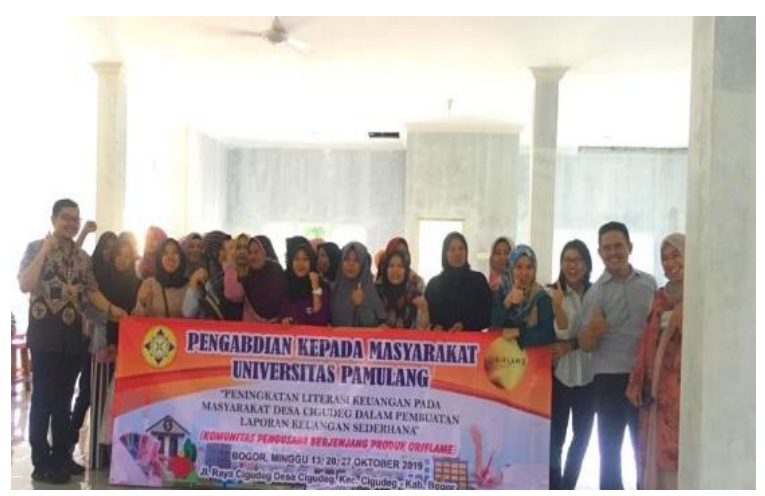

PKM Setelah Pelatihan

\section{KESIMPULAN}

Pelatihan literasi keuangan dalam membuat laporan laporan keuangan sederhana belum memberikan perubahan pada nilai rata-rata hasil belajar post-test sehingga diperlukan pelatihan lebih lama agar hasil belajar berubah sesuai hasil yang 
diharapkan tim pengabdi. Namun, pengetahuan mengenai pembuatan laporan keuangan secara sederhana pada masyarakat sekitar Desa Cigudeg dan komunitas pengusaha berjenjang produk Oriflame sudah mengalami perubahan signifikan sehingga dapat ditarik kesimpulan masyarakat Desa Cigudeg khususnya RT 04 dan komunitas pengusaha berjenjang produk Oriflame dapat belajar secara cepat dan memberikan efek positif pada pelatihan berikutnya.

\section{SARAN}

PKM dilaksanakan sebagai kerjasama dosen prodi S1 Akuntansi Universitas Pamulang dengan Masyarakat Desa Cigudeg khususnya RT 04 dan komunitas berjenjang produk Oriflame ini memang masih banyak kekurangan dan keterbatasan, kami menyarankan agar di masa yang akan datang melibatkan pengusaha UMKM setempat sehingga para UMKM setempat mengetahui dasar-dasar penulisan laporan keuangan.

\section{UCAPAN TERIMAKASIH}

Terima kasih yang sebesar-besarnya kami tujukan kepada masyarakat Desa Cigudeg khususnya RT 04 dan komunitas pengusaha berjenjang produk Oriflame yang berlokasi di Kampung Cijeuray rt 04 Desa Cigudeg
Kabupaten Bogor yang telah menyambut tim pengabdi dengan sangat baik dan bersedia meluangkan waktunya selama kegiatan.

\section{REFERENSI}

Badan Pusat Statistik Kabupaten Bogor (2019. 21 September). Kecamatan Cigudeg Dalam Angka 2018.

Effendi, Rizal. (2015). Accounting Principles: Prinsip-Prinsip Akuntansi Berbasis SAK ETAP Palembang: PT.Rajagrafindo Persada.

Ikatan Akuntansi Indonesia. (2009). Standar Akuntansi Keuangan Tanpa Akuntabilitas Publik (SAK ETAP). Penerbit Dewan Standar Akuntansi Indonesia.

Irawati, Wiwit et. all. (2019) Pengenalan Dasar-Dasar Investasi Bagi Ibu-Ibu PKK Kelurahan Babakan, Setu, Tangerang Selatan. Jurnal Pengabdian Kepada Masyarakat (ABDIMISI) Vol 1 No.1, Hal 18-23.

Suwardjono. (2008). Teori Akuntansi Perekayasaan Pelaporan Keuangan.Yogyakarta : BPFE 